\title{
IPTEKS PENGENDALIAN INTERN TERHADAP ASET TETAP DI KANTOR PENGAWASAN DAN PELAYANAN BEA DAN CUKAI TIPE MADYA PABEAN C / KPPBC TMP C BITUNG
}

\author{
Timons P. M. Mamentu ${ }^{1}$, Novi S. Budiarso ${ }^{2}$ \\ ${ }^{1,2}$ Jurusan Akuntansi, Fakultas Ekonomi dan Bisnis, Universitas Sam Ratulangi, Jl. Kampus Bahu, Manado, \\ 95115, Indonesia \\ E-mail: tmamentu@gmail.com
}

\begin{abstract}
This article discusses about the implementation of IPTEKS of internal control on fixed assets. The method used in this article is how to implement the internal control structure. In order to implement the internal control well, an organization must fulfil the 5 aspect in internal control, which are: environment control, risk grading, information and communication, supervision, and activity control. It is suggested that Office of Customs and Excise Branch Bitung to keep maintaining the applied internal control..
\end{abstract}

Keywords: internal control, service, fixed assets

\section{PENDAHULUAN}

Suatu instansi yang telah berjalan tidak boleh tidak memonitor segala aktiva tetap/aset tetap yang dimiliki, instasi harus memiliki cara untuk menjaga seluruh aktiva tetap yang dimiliki untuk demi menjalakan aktivitas ataupun kegiatan-kegiatan yang akan dilakukan, aktiva tetap yang diperlukan dalam suatu instansi seperti bangunan, peralatan, perabotan dan mesin-mesin yang memiliki manfaat atau dapat digunakan dalam waktu lebih dari satu periode. Setiap persediaan aset tetap dilakukan secara periodik dengan tujuan untuk mengetahui aset tetap rusak ataupun hilang. KPPBC TMP C Bitung melaksanakan pengendalian asset tetap sesuai dengan Peraturan Menteri Keuangan Republik Indonesia Nomor 118/PMK.06/2017 tentang pedoman pelaksanaan penilaian kembali barang milik negara. Pengendalian intern adalah salah satu cara untuk mengamankan aktiva tetap yang dimiliki instansi. Pengendalian intern yang baik akan menghasilkan informasi laporan keuangan yang benar dari suatu aktiva tetap. Dalam pengendalian intern memiliki prosedur agar tercapainya suatu pengendalian intern yang baik, prosedur yang harus dilakukan adalah setiap pimpinan harus memiliki sikap dan pandangan yang professional demi meningkatkan hasil yang telah dicapai. Pimpinan perlu menerapkan sistem pengendalian internal agar tidak terjadinya penyimpangan ataupun hal-hal yang dapat merugikan instansi.

Aset tetap adalah asset yang diperoleh secara sah dengan manfaat penggunaan lebih dari 12 bulan dan dapat digunakan dalam kegiatan operasional dan tidak untuk dijualkan. Di KPPBC TMP C Bitung, otorisasi dalam pengadaan ataupun penggunaan aset tetap adalah pejabat yang memiliki wewenang serta bertanggung jawab dalam kebijakan pengelolaan asset tetap. KPPBC TMP C Bitung melaporkan penyampaian rekonsiliasi kepada Kanwil KPPBC Manado, KPPBC TMP C Bitung wajib melaporkan dan mencatat seluruh transaksi pengeluaran atas aset tetap yang menggunakan anggaran pendapatan dan belanja negara. Maka dari itu perlu adanya pengendalian intern yang baik agar seluruh aset maupun laporan terjaga dengan baik.

\section{TINJAUAN PUSTAKA}

Pengendalian Intern. Menurut IAI (Ikatan Akuntansi Indonesia) (2001: 319.2) Pengendalian intern sebagai suatu proses yang dijalankan oleh dewan komisaris, manajemen 
dan personel lain entitas yang didesain untuk memberikan keyakinan memadai tentang pencapaian tiga golongan tujuan berikut ini: (a) Keandalan laporan keuangan, (b) Efektivitas dan efisiensi operasi, dan (c) Kepatuhan terhadap hukum yang berlaku. Dari pernyataan diatas, pengendalian intern dapat diartikan sebagai sistem yang memiliki berbagai unsur dan tidak terbatas dalam metode pengendalian yang dianut oleh bagian akuntansi dan keuangan yang meliputi pengendalian dalam anggaran, biaya standar, program pembimbingan atau pelatihan pegawai dan unit dalam melakukan pemeriksaan intern. Tujuan dari pengendalian intern agar kekayaan dari suatu organisasi terjaga, mendapatkan hasil yang valid dan benar adanya dalam laporan yang dicatat, kegiatan opesaional berjalan dengan efektif dan efisien, serta dipatuhinya peraturan dan kebijakan yang dibuat dalam suatu instansi.

Aset Tetap/Aktiva Tetap. Menurut Pernyataan Standar Akuntansi Keuangan (PSAK) No. 16 (2011) aset tetap adalah aset berwujud yang penggunaannya lebih dari satu periode dan dimiliki oleh perusahaan untuk digunakan dalam operasional, untuk tujuan administratif. Menurut Rudianto (2012:256) mengemukakan bahwa aset tetap adalah barang berwujud milik perusahaan yang sifatnya relatif permanen dan digunakan dalam kegiatan perusahaan, bukan untuk diperjualbelikan. Sesuai dengan Peraturan Menteri Keuangan Republik Indonesia Nomor 118/PMK.06/2017 aset tetap adalah barang yang diperoleh berdasarkan perolehan yang sah yang berwujud dengan manfaat melebihi 12 bulan dan digunakan dalam kegiatan operasional dan tidak untuk diperjualkan. Pengguna ataupun pengelola barang adalah pejabat yang memiliki wewenang serta bertanggung jawab dalam kebijakan serta pedoman dalam penggunaan barang tersebut.

Unsur Pengendalian Intern. Dalam pengendalian intern, terdapat 5 unsur agar pengendalian intern dapat berjalan baik (menurut COSO) : lingkungan pengendalian, penilaian resiko, informasi dan komunikasi, pemantauan, dan aktivitas pengendalian.

\section{METODE DAN TEKNIK PENERAPAN IPTEKS}

\subsection{Metode Penerapan Ipteks}

Metode yang digunakan dalam penerapan ipteks adalah implementasi struktur pengendalian intern aktiva tetap pada Kantor Pengawasan dan Pelayanan Bea dan Cukai TMP C Bitung (menurut COSO).

\subsection{Teknik Penerapan Ipteks}

Teknik dalam penerapan IPTEKS adalah membantu dalam proses pengendalian aktiva tetap serta melakukan pengamatan pada KPPBC TMP C Bitung menggunakan unsur pengendalian intern (menurut COSO): Lingkungan Pengendalian, Penilaian Resiko, Informasi dan Komunikasi, Pemantauan, Aktivitas Pengendalian.

\section{PEMBAHASAN}

\subsection{Gambaran Objek Penerapan Ipteks}

Kantor Pengawasan dan Pelayanan Bea dan Cukai Tipe Madya Pabean C Bitung bertlokasi di J1. D. S. Sumolang No.1, Kota Bitung, Provinsi Sulawesi Utara. KPPBC TMP C Bitung mempunyai visi "Menjadi Kantor Pengawasan dan Pelayanan yang terbaik dan katalisator pertumbuhan ekonomi dan industry di Wilayah Indonesia Bagian Timur'. Dengan misi "Kami memberikan pelayanan terbaik dan responsif di bidang Kepabeanan dan Cukai; Kami melakukan pengawasan secara efektif untuk melindungi masyarakat; Kami memfasilitasi pengembangan ekonomi di Wilayah Indonesia Bagian Timur; Kami melakukan upaya intensif dalam mengamankan dan mengoptimalkan penerimaan negara". KPPBC TMP C Bitung melaksanakan tugas perumusan dan pelaksanaan kebijakan dalam bidang pengawasan, penegakan hukum, pelayanan dan optimalisasi penerimaan negara di bidang kepabeanan dan cukai sesuai dengan peraturan perundang-undangan. Adapun fungsi dari KPPBC TMP C Bitung dalam menyelenggarakan tugasnya, perumusun dan pelaksanaan 
kebijakan, penyusunan norma, standar, prosedur, serta kriteria, pemberian bimbingan teknis dan supervise, palaksanaan pemantauan, evaluasi, dan pelaporan, di bidang kepabeanan dan cukai, pelaksanaan administrasi DJBC dan pelaksanaan fungsi lainnya dari Menteri Keuangan. KPPBC TMP C Bitung memiliki 5 seksi, Subbagian Umum, Seksi Kepabeanan dan Dukungan Teknis, Seksi Penindakan dan Penyidikan, Seksi Perbendaharaan, Seksi Kepatuhan Internal dan Penyuluhan. Wilayah pengawasan dan pelayanan KPPBC TMP C Bitung : Kota Bitung; Kabupaten Minahasa Utara pada Kec. Wori, Kec. Talawaan, Kec. Kalawat, Kec. Likupang Selatan, Kec. Likupang Timur, Kec. Dimembe, Kec. Airmadidi, Kec. Kauditan, Kec. Kema; Kabupaten Minahasa pada Kec. Kombi, Kec. Lembean Timur, Kec. Kakas, Kec. Kakas Barat, Kec. Remboken, Kec. Langowan Barat, Kec. Langowan Selatan, Kec. Langowan Timur, Kec. Langowan Utara, Kec. Tompaso, Kec. Tompaso Barat, Kec. Tondano Timur, Kec. Eris; Kabupaten Minahasa Tenggara; Kabupaten Bolaang Mongondow Timur; Kabupaten Bolaang Mongondow Selatan. KPPBC TMP C Bitung memiliki 5 Pos Pengawasan dan 1 Pos Bantau Pelayanan dalam wilayah kerjanya, yakni : (1) Pos Pengawasan Kema, (2) Pos Pengawasan Belang, (3) Pos Pengawasan Kotabunan, (4) Pos Pengawasan Likupang, (5) Pos Pengawasan Bitung, dan (6) Pos Bantu Pelayanan Ratatotok.

\subsection{Pembahasan}

Agar pengendalian intern aset tetap/aktiva tetap dapat berjalan dengan baik, 5 unsur ini harus dipenuhi :

1. Lingkungan pengendalian. Lingkungan pengendalian menentukan suasana terhadap suatu instansi yang akan memengaruhi kesadaran dari pengendalian dari orang-orangnya. Instansi harus memiliki suatu entitas yang mempengaruhi lingkungan pengendalian. Fator-faktor yang mempengaruhi entitas dalam lingkungan pengendalian. Instansi harus menetapkan tujuan yang akan dicapai sehingga kegiatan-kegiatan yang akan dilakukan demi mencapai tujuan yang ditetapkan serta filosofi instansi. Instansi membuat peraturan ataupun kebijakan yang dituruti seluruh pegawai baik seacara verbal maupun tertulis dalam penggunaan ataupun pemakaian aktiva tetap agar tidak terjadi hal yang merugikan instansi seperti aktiva rusak atau hilang serta perlu adanya bimbingan ataupun pelatihan terhadap pegawai dalam penggunaan aktiva seperti berbasis computer sehingga tidak terjadi kerusakan atau bahkan kehilangan dokumen dan laporan penting disimpan, pelatihan dilakukan dengan waktu minimal 3 bulan. Instansi harus memiliki struktur organisasi yang jelas beserta bagian-bagiannya dengan wewenang dan tanggung jawab yang diberikan bagi setiap pegawai. Setiap pegawai harus memiliki komitmen terhadap kompetensi dalam pengetahuan maupun keahlian terutama untuk pegawai yang ditugaskan dalam penjagaan dan pemeliharaan aktiva tetap. KPPBC TMP C Bitung perlu menambah pegawai agar tugas yang diberikan dapat berjalan dengan baik dan lancar.

2. Penilaian resiko. Penilaian resiko perlu mengidentifikasi resiko-resiko yang berdampak pada aktiva tetap yang dimiliki instansi, seperti perubahan lingkungan,operasi pasar, pertumbuhan yang cepat dan signifikan, produk atau aktivitas baru, restrukturisasi instansi, perubahan kebijakan sehingga laporan yang dihasilkan wajar dan dapat diandalkan serta sesuai dengan kondisi dan nilai dari suatu aktiva tersebut yang mencakup pertimbangan khusus bagi pimpinan untuk mengambil keputusan.

3. Informasi dan komunikasi. Dalam informasi dan komunikasi, instansi akan mengidentifikasi, mengumpulkan, menganalisis, mencatat serta melaporkan informasi transaksi entitas agar akuntabilitas dari aktiva-aktiva terjaga. Komunikasi antara seluruh pegawai dalam memberikan informasi terhadap akvita tetap. Informasi harus valid, informasi disediakan tepat waktu, diukur dengan tepat dari nilai keuangan, pencatatan yang akurat saat terjadi transaksi.

4. Pemantauan. Instansi melakukan pengawasan terhadap aktiva tetap mulai dari nilai atau harga dari aktiva tetap, pencatatan terhadap aktiva tetap, bagian yang melakukan otorisasi 
aktiva tetap, pengeluaran dana terhadap aktiva tetap, penyusutan dari aktiva tetap yang dilakukan secara terus-menerus, dan asuransi dari aktiva tetap, serta penghapusan dan pelepasan terhadap suatu aktiva tetap.

5. Aktivitas pengendalian. Aktivitas pengendalian akan memastikan tidak ada pegawai yang bekerja tidak seimbang, mengevaluasi proses otorisasi apakah terdapat resiko yang mengacu pada proses perolehan informasi, melakukan pemeriksaan secara langsung dan tidak langsung pada aktiva dan laporan catatan, contoh pemeriksaan secara langsung seperti, mengecek setiap aktiva (komputer) apakah terjadi kerusakan atau apakah aktiva tersebut masih layak untuk dipakai, contoh pemeriksaan tidak langsung seperti, mereview dokumen-dokumen yang pengeluaran nota yang mengotorisasi aktiva. Instansi melakukan evaluasi kembali terhadap prosedur dan kebijakan yang ditetapkan telah dilaksanakan sesuai dengan yang telah ditetapkan serta mengevaluasi kinerja dari setiap aktiva tetap, mengevaluasi laporan secara terinci dari akun neraca saldo, laporan pengeluaran dana kas berdasarkan pelanggan atas aktiva, merangkaikan data operasi non keuangan dan data keuangan. Instansi mengikuti dan melakukan update terhadap pogram-program agar keamanan dari data-data laporan aktiva semakin terjaga, memastikan bahwa seluruh data transaksi aktiva telah lengkap dan terkumpul, mulai dari nota pengeluaran, surat ijin pengadaan, surat disposisi aktiva, dan surat atau data lainnya sebelum melakukan pengolahan. Instansi harus melakukan pada bagian ataupun pegawai yang dituugaskan dalam melakukan penjagaan dan pemeliharaan aktiva. Instansi harus mengikuti asuransi dari setiap aktiva yang dimiliki sehingga apabila terjadi kerusakan, instansi tidak akan mendapat kerugian yang besar. Instansi perlu melakukan pembatasan akses terhadap aktiva tetap untuk mencegah tidak terjadinya penyalahgunaan terhadap aktiva. Setelah mengevalusi seluruhnya, instansi melakukan verifikasi, kinerja dari tiap pegawai, integritas dalam sistem proses transaksi serta kebenaran dan kelengkapan dari data-data yang dievaluasi.

\section{KESIMPULAN DAN SARAN}

\subsection{Kesimpulan}

Pengendalian intern yang dilakukan di KPPBC TMP Bitung telah berjalan dengan baik, teratur, dan sistematis serta telah memenuhi unsur-unsur dalam pengendalian intern. Aset tetap yang dimiliki terjaga dan dipelihara, laporan dan data-data transaksi mengenai aset disimpan dan dijaga dengan baik. Kegiatan operasional telah berjalan dengan efektif dan efesien.

\subsection{Saran}

Saran yang bisa diberikan kepada KPPBC TMP C Bitung, kiranya mempertahankan pengendalian intern yang telah diterapkan serta ketaatan dan kekompakan dalam melaksanakan tugas yang diberikan agar mendapat hasil yang semakin baik.

\section{DAFTAR PUSTAKA}

Peraturan Presiden Republik Indonesia Nomor 75 Tahun 2017 Tentang Penilaian Kembali Barang Milik Negara/Daerah

Peraturan Pemerintah Republik Indonesia Nomor 27 Tahun 2014 Tentang Pengelolaan Barang Milik Negara/Daerah

Peraturan Menteri Keuangan Republik Indonesia Nomor 1/PMK.06/2013 Tentang Penyusutan Barang Milik Negara Berupa Aset Tetap Pada Entitas Pemerintah Pusat 
Peraturan Menteri Keuangan Nomor: 90/PMK.06/2014 Tentang Perubahan Atas Peraturan Menteri Keuangan Nomor 1/PMK.06/2013 Tentang Penyusutan Barang Milik Negara Berupa Aset Tetap Pada Entitas Pemerintah Pusat

Surat Edaran Direktur Jenderal Bea dan Cukai Nomor: SE-73/PJ/2015 Tentang Penunjuk Pelaksanaan Peraturan Direktur Jenderal Pajak Nomor Per-37/PJ/2015 Tentang Tata Cara Pengajuan Permohonan Dan Pengadministrasian Penilaian Kembali Aktiva Tetap Untuk Tujuan Perpajakan Bagi Permohonan Yang Diajukan Pada Tahun 2015 dan Tahun 2016.

Peraturan Menteri Keuangan Republik Indonesia Nomor 118/PMK.06/2017 Tentang Pedoman Pelaksanaan Penilaian Kembali Barang Milik Negara.

Jesella Lourina Makaluas, Winston Pontoh. Pengendalian Intern Aset Tetap pada PT. Lumbung Berkat Indonesia. Jurnal Accountability, 7(10), 1-10.

Hall, James. 2011. Sistem Informasi Akuntansi, Edisi 4, Jakarta : Salemba Empat

Hartadi, Bambang. 1987. Auditing: Suatu Pedoman Pemeriksaan Akuntan Tahap Pendahuluan . BPFE, Yogyakarta

Komite SPAP Ikatan Akuntan Indonesia (IAI), 2001, Standar Profesional Akuntan Publik. Jakarta : Salemba Empat.

Ikatan Akuntansi Indonesia. 2011. PSAK (Revisi 2011) : Aset Tetap, Jakarta : IAI

Rudianto. 2012. Akuntansi Pengantar. Jakarta : Penerbit Erlangga 